\section{Debitus grisailles for stained-glass conservation: an analytical study}

\section{As grisalhas Debitus para conservação de vitral: um estudo analítico}

\author{
CARLA MACHADO $0^{1,2 *}$ \\ ANDREIA MACHADO $0^{1,2}$ \\ TERESA PALOMAR ${ }^{3}$ \\ LUÍS CERQUEIRA \\ ALVES $^{4}$ \\ MÁRCIA VILARIGUES ${ }^{1,2}$ \\ 1. Departament of Conservation \\ and Restoration, Faculty of \\ Science and Technology, NOVA \\ University of Lisbon, Portugal \\ 2. Research Unit VICARTE - \\ Glass and Ceramics for the \\ Arts, Faculty of Science and \\ Technology, NOVA University \\ of Lisbon, Portugal \\ 3. Institute of Ceramic and \\ Glass, Spanish National \\ Research Council (ICV-CSIC), \\ Madrid, Spain \\ 4. C2TN, IST/CTN, University \\ of Lisbon, Portugal \\ *cf.machado@campus.fct.unl.pt
}

\section{KEYWORDS}

Glass painting

Stained-glass windows

Grisailles

Debitus

Conservation

Analytical study

\title{
Resumo
}

A grisalha é uma das pinturas vítreas mais antigas e mais usadas na produção de painéis de vitral, e Debitus é uma das marcas comerciais mais conhecidas. As suas grisalhas são frequentemente utilizadas para reintegração cromática em restauro de vitral. Este artigo apresenta a análise química, morfológica e térmica de cinco grisalhas da Debitus, avaliando as suas propriedades antes e depois da cozedura com o objetivo de compreender a sua futura estabilidade. A caracterização foi realizada por microscopia ótica, microscopia eletrónica de varrimento, emissão de raios $\mathrm{X}$ induzida por partículas, difração de raios $\mathrm{X}$ e termografia de infravermelho. Este estudo demonstrou uma relação equilibrada entre os diferentes componentes e uma boa interdifusão no vidro por parte destes, tal como um comportamento térmico consistente entre eles e com o vidro, o que indica uma boa estabilidade e durabilidade destes materiais.

\section{PALAVRAS-CHAVE}

Pintura sobre vidro

Vitral

Grisalha

Debitus

Conservação

Estudo analítico 


\section{Introduction}

Grisaille is a glass-based paint applied in the production of stained-glass panels, normally used for the creation of outlines and shadows [1]. These paints generally appear with dark colours (black, brown); however, it is also possible to find light hues, as white [2]. The grisailles are produced by mixing metals oxides with a ground lead-based glass. The obtained powder is mixed with a vehicle agent, such as vinegar and water, which will give the necessary plasticity to paint, and gum arabic as a temporary binding agent [1-3]. After fired, at temperatures between 650 and $700{ }^{\circ} \mathrm{C}$, a thin layer of colourless glass with the metal oxides embedded is formed on the top of the glass panel, as showed in Figure $1[2,4]$.

These paints were initially produced in the stained glass workshops by the glass painters themselves, as reported in the historical written sources [1]; however, glass paint manufacturers, like Lacroix \& $\mathrm{C}^{\mathrm{ie}}$ founded in 1855 in Paris, made their products commercially available during the 19th century [5]. The separation between the manufacturer and the user resulted in conservation problems that persist until today, such as the incompatibility between the painting materials and the glass panels that can lead to the detachment of the paint layers [6].

During the middle of the 2oth century, Lacroix \& $C^{\text {ie }}$ stopped the production because the demand was not enough to be rentable. However, at the end of the zoth century, the French section of the International Institute of Conservation (IIC), in partnership with the Laboratoire de Recherche des Monuments Historiques (LRMH), felt the need to create new formulations of glass paints to be used in conservation and restoration works. This investigation was trusted to Hervé Debitus, a conservator and specialist in painting on glass [7].

In the article Recherche pour une formulation nouvelle de grisailles, published in 1991, Debitus introduced new grisailles formulations based, not only on medieval treatises, but also on the manuscripts of Lacroix \& $C^{\text {ie }}[8]$. These paints started to become available commercially since this date and they are sold until nowadays, being one of the most used in contemporary art and for conservation and restoration works.

The Debitus grisailles are applied in the conservation and restoration of stained-glass windows for the chromatic reintegration during the process of filling losses. To avoid future conservation problems in the historical windows, it is important not only to understand the chemical and physical properties of the materials of the windows itself, but also the materials used in the conservation and restoration procedures. Therefore, the objective of this work was to characterise the commercial grisailles from Debitus to better understand their future stability and compatibility with the historical stained-glass windows.

\section{Methodology}

\section{Materials selection}

For the evaluation of the materials, five of the most common grisailles were selected: 1) one black (Noir Ordinaire); 2) two browns (Brun XIII and Brun XVI); 3) two whites (Depoli Incolore and Mousseline). This choice was made by their representativeness within the colours found on historical grisailles. The commercial grisailles were prepared by mixing them with water and gum arabic (less than 1 wt. \%) and painted on $2 \mathrm{~cm} \times 2 \mathrm{~cm}$ squares on the non-tinned side of float glasses (soda-lime silicate glasses). The grisailles were fired in a side-heated electric furnace BARRACHA-Model E1. They were heated with a temperature ramp of $3^{\circ} \mathrm{C} / \mathrm{min}$ up to $680^{\circ} \mathrm{C}$, followed by a dwell of 30 minutes and a slow cooling. The grisailles were studied before and after the firing process to assess the changes in the chemical composition and colour during the thermal treatment (Figure 2).
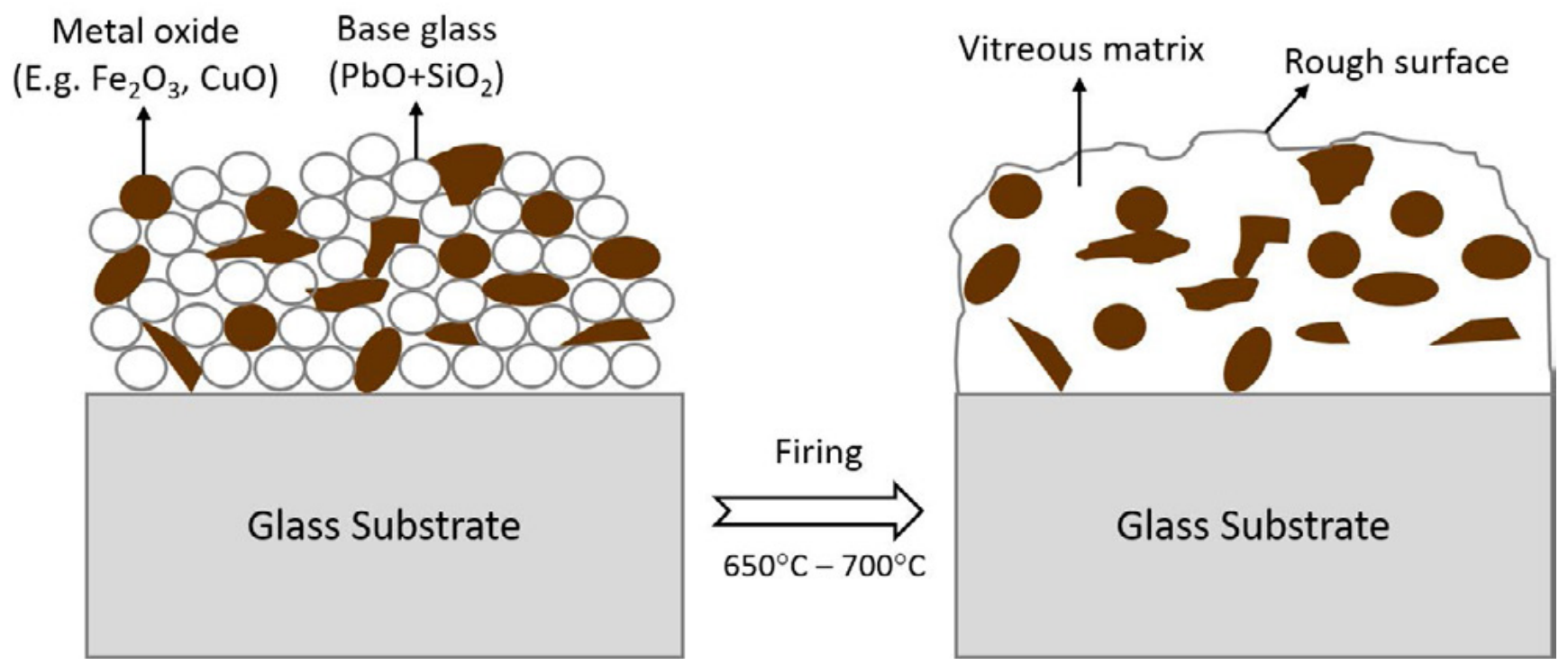

Figure 1. Schematic representation of grisaille paint layer in cross-section, before and after firing (following [2]). 


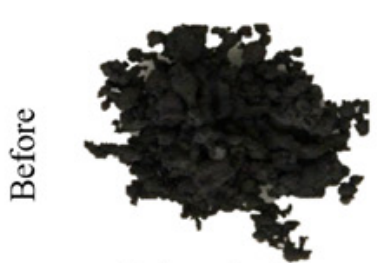

Noir ordinaire

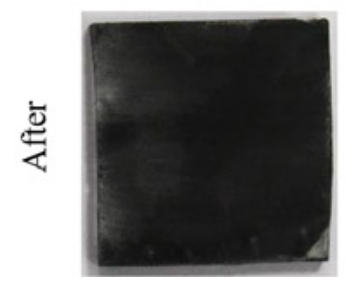

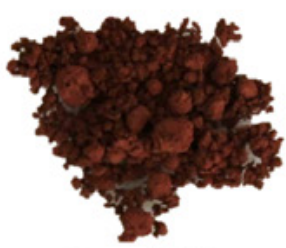

Brun XIII

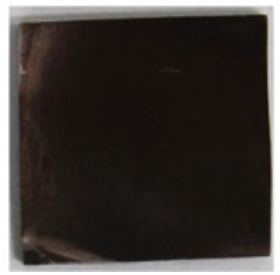

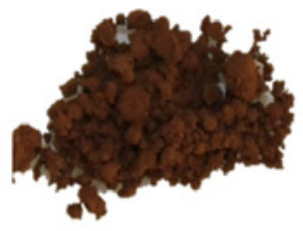

Brun XVI

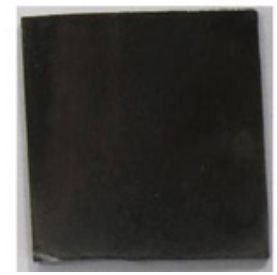

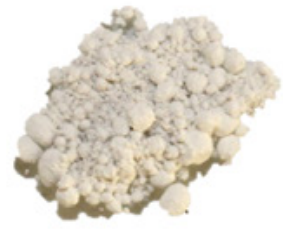

Mousseline

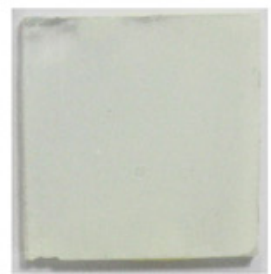

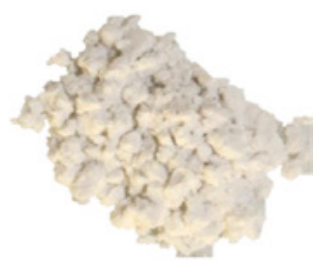

Depoli incolore

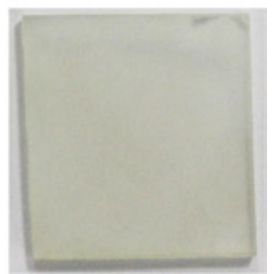

Figure 2. Grisailles selected for the study, before and after firing.

\section{Analytical techniques}

The samples were characterised before and after firing with a set of different techniques: 1) optical microscopy (OM); 2) scanning electron microscopy (SEM-EDS); 3) particle induced X-ray emission ( $\mu$-PIXE); 4) X-ray diffraction (XRD); 5) infrared thermography.

In order to analyse the grisaille cross-sections for $\mu$-PIXE and SEM-EDS, the painted grisailles were cut with a steel wire with a diamond point and mounted in epoxy resin (Araldite 2020) from Huntsman and polished with up to 4000 grit with a $\mathrm{SiC}$ paper.

The $\mu$-PIXE analysis were made in the IST 2.5 MV Van de Graaff accelerator facility using an OM150 Oxford Microbeams scanning nuclear microprobe. The produced $\mathrm{X}$-rays were collected with a $160 \mathrm{eV}$ resolution Bruker SDD detector. With the microprobe beam scanning system, elemental distribution maps were obtained, and specific regions of interest were selected for quantitative analysis. Operation and basic data manipulation was achieved using OMDAQ software; quantitative analyses were done with the GUPIXWIN program. Each sample was analysed in three different areas/regions and the average of the results in oxides was calculated and normalised to $100 \mathrm{wt}$. \%.

The morphology of the grisaille powders was observed by transmitted light in an optical microscopy under plane and cross-polarised light. The microscope, an Axioplan 2 from Zeiss, is equipped with a halogen light HAL10o and a digital camera (Nikon DMX1200F).

The scanning electron microscope, complies a Hitachi S2400 model equipped with a Rontec standard EDS detector, operating at a beam acceleration voltage of $20 \mathrm{kV}$ for analyses, and a backscattered electron (BSE) detector for imaging.

$\mathrm{X}$-ray diffraction was applied for the identification of the crystallographic phases. It was performed on a Benchtop X-Ray Diffractometer RIGAKU model MiniFlex II, using a monochromatic X-ray source ( $\mathrm{Cu} \mathrm{K \alpha}$ line) operated at $30 \mathrm{kV}$ of acceleration voltage and $15 \mathrm{~mA}$ current. The spectra were acquired between 10 and $90^{\circ}$ at $2 \%$ min. The identification was made by comparison with the RRUFF database [9].

The characterisation of the surface thermal behaviour of grisailles was carried out by infrared thermography using a FLIR Therma-CAM B4 (7.5 to $13 \mu \mathrm{m}$ wavelength range, -20 to $+130{ }^{\circ} \mathrm{C}$ temperature range and $0.08{ }^{\circ} \mathrm{C}$ of temperature accuracy) equipped with a $25^{\circ} \mathrm{FOV}$ (Field of View) lent. As the analyses did not aim to acquire accurate temperature measurements but to detect thermal anomalies and perform active thermography calculations, emissivity was set to a constant value (0.96). The camera was set at $40 \mathrm{~cm}$ distance from the samples, which were placed vertically on a support covered with an aluminium foil with the painted side facing to the camera. For thermal excitation, a heater with a hot air flux located at $40 \mathrm{~cm}$ from the grisaille samples was used. The acquisition lasted 10 minutes: 5 minutes during heating and 5 minutes cooling after turning off the heating source with a frequency of acquisition of one capture every 30 seconds. The analyses were done in a dark room with an environmental temperature $\sim 20^{\circ} \mathrm{C}$ throughout the experiment.

\section{Results and Discussion}

\section{Chemical and crystallographic characterisation}

The theoretical composition of the grisailles was published in 1991 by H. Debitus [8], which are reproduced in Table 1 for the grisailles selected. It is possible to observe that some of the grisailles are produced using a mixture of the previously prepared ones. Nowadays, due to the patent protection, the information given by the company is limited; for example, Debitus only says that the grisailles are constituted by a mixture of a "Rocaille" $\left(5 \mathrm{SiO}_{2} \cdot 4 \mathrm{PbO}\right)$ with metal oxides as colorant [10].

The performed analysis of the grisailles by $\mu$-PIXE and XRD determined the chemical composition and the crystallographic phases (Table 2). 
Comparing the results from Table 2 with the information on Table 1 , it is possible to notice a difference between the theoretical compositions proposed by Debitus in 1991 [8] and the compositions analysed by $\mu$-PIXE in the selected grisailles. In contrast to the theoretical compositions, manganese was used together with iron as colouring agent in the black paints (grisaille Noir Ordinaire), as well as tin and aluminium which opacify the paint to obtain a white material in the grisaille Depoli Incolore.

The compositions in the darker grisailles do not present significant changes before and after firing, just a slight increase on the lead and silica concentrations after firing and, by consequence, a decrease in the metallic oxides, mainly in the iron concentration. But in the white grisailles, it is possible to see a significant loss of lead and aluminium in the Mousseline and Depoli Incolore grisailles, respectively. This phenomenon can be related to the interdiffusion and penetration of these elements into the glass substrate, to their volatilization during the firing process or to the experimental procedure.

Regarding the crystallographic characterisation, in the darker grisailles, iron compounds were identified in

Table 1. Compositional percentage from the selected Debitus grisailles according to the original formulation [8].

\begin{tabular}{|c|c|c|c|c|c|c|}
\hline \multicolumn{2}{|c|}{ Components, raw materials } & \multicolumn{5}{|c|}{ Grisailles studied, theoretical composition (\%) } \\
\hline Name & Formula & Noir Ordinaire & Brun XIII & Brun XVI & Mousseline & Depoli Incolore \\
\hline Iron oxide & $\mathrm{Fe}_{3} \mathrm{O}_{4}$ & 41.2 & - & - & - & - \\
\hline Tin oxide & $\mathrm{SnO}_{2}$ & - & - & - & 33.3 & - \\
\hline Fused agent & $5 \mathrm{SiO}_{2}: 4 \mathrm{PbO}$ & 58.8 & - & - & 66.7 & 100 \\
\hline Grisaille Noir Ordinaire & $7 \mathrm{Fe}_{3} \mathrm{O}_{4}: 10\left(5 \mathrm{SiO}_{2}: 4 \mathrm{PbO}\right)$ & - & 37 & 30.3 & - & - \\
\hline Grisaille Rouge no. 2 & $1 \mathrm{Fe}_{2} \mathrm{O}_{3}: 2\left(5 \mathrm{SiO}_{2}: 4 \mathrm{PbO}\right)$ & - & 37 & - & - & - \\
\hline Grisaille Rouge no. 4 & $\mathrm{I}\left(2 \mathrm{Fe}_{2} \mathrm{O}_{3}: \mathrm{ZnO}\right): 2\left(5 \mathrm{SiO}_{2}: 4 \mathrm{PbO}\right)$ & - & - & 9.1 & - & - \\
\hline Grisaille Brun Clair & $7\left(2 \mathrm{Fe}_{2} \mathrm{O}_{3}: \mathrm{ZnO}\right): 10\left(5 \mathrm{SiO}_{2}: 4 \mathrm{PbO}\right)$ & - & 25.9 & 60.6 & - & - \\
\hline
\end{tabular}

Table 2. Compositional (wt. \%) and crystallographic phases from the select Debitus grisailles, before and after the firing process, obtained by $\mu$-PIXE and XRD analysis.

\begin{tabular}{|c|c|c|c|c|c|c|c|c|c|c|}
\hline & \multirow[b]{2}{*}{ Firing process } & \multicolumn{8}{|c|}{ Chemical composition analysed by PIXE (wt. \%) } & \multirow[b]{2}{*}{ Crystallographic phases } \\
\hline & & $\mathrm{Al}_{2} \mathrm{O}_{3}$ & $\mathrm{SiO}_{2}$ & MnO & $\mathrm{Fe}_{2} \mathrm{O}_{3}$ & Zno & $\mathrm{SnO}_{2}$ & Pbo & Others & \\
\hline \multirow[t]{2}{*}{ Noir Ordinaire } & Before & 0.92 & 18.3 & 6.3 & 21.5 & 0.02 & - & 52.4 & 0.66 & $\begin{array}{l}\text { Hematite }\left(\mathrm{Fe}_{2} \mathrm{O}_{3}\right) \\
\text { Magnetite }\left(\mathrm{Fe}_{3} \mathrm{O}_{4}\right) \\
\text { Jacobsite }\left(\mathrm{MnFe}_{2} \mathrm{O}_{4}\right)\end{array}$ \\
\hline & After & 0.73 & 22.9 & 5.2 & 18.7 & 0.02 & - & 52.6 & 0.75 & $\begin{array}{l}\text { Kentrolite }\left(\mathrm{Pb}_{2} \mathrm{Mn}_{2} \mathrm{O}_{2}\left(\mathrm{Si}_{2} \mathrm{O}_{7}\right)\right) \\
\text { Hematite }\left(\mathrm{Fe}_{2} \mathrm{O}_{3}\right) \\
\text { Magnetite }\left(\mathrm{Fe}_{3} \mathrm{O}_{4}\right)\end{array}$ \\
\hline \multirow[t]{2}{*}{ Brun XIII } & Before & 0.35 & 15.4 & 2.4 & 26.7 & 4.6 & - & 50.2 & 0.32 & $\begin{array}{l}\text { Franklinite }\left(\mathrm{ZnFe}_{2} \mathrm{O}_{4}\right) \\
\text { Hematite }\left(\mathrm{Fe}_{2} \mathrm{O}_{3}\right) \\
\text { Magnetite }\left(\mathrm{Fe}_{3} \mathrm{O}_{4}\right)\end{array}$ \\
\hline & After & 0.27 & 18.7 & 1.8 & 22.2 & 4.3 & - & 52.3 & 0.41 & $\begin{array}{l}\text { Kentrolite }\left(\mathrm{Pb}_{2} \mathrm{Mn}_{2} \mathrm{O}_{2}\left(\mathrm{Si}_{2} \mathrm{O}_{7}\right)\right) \\
\text { Franklinite }\left(\mathrm{ZnFe}_{2} \mathrm{O}_{4}\right) \\
\text { Hematite }\left(\mathrm{Fe}_{2} \mathrm{O}_{3}\right) \\
\text { Magnetite }\left(\mathrm{Fe}_{3} \mathrm{O}_{4}\right)\end{array}$ \\
\hline \multirow[t]{2}{*}{ Brun XVI } & Before & 0.41 & 17.7 & 2.3 & 22.7 & 6.5 & - & 49.8 & 0.56 & $\begin{array}{l}\text { Franklinite }\left(\mathrm{ZnFe}_{2} \mathrm{O}_{4}\right) \\
\text { Hematite }\left(\mathrm{Fe}_{2} \mathrm{O}_{3}\right) \\
\text { Magnetite }\left(\mathrm{Fe}_{3} \mathrm{O}_{4}\right)\end{array}$ \\
\hline & After & 0.38 & 20.6 & 1.90 & 20.1 & 6.3 & - & 50 & 0.64 & $\begin{array}{l}\text { Kentrolite }\left(\mathrm{Pb}_{2} \mathrm{Mn}_{2} \mathrm{O}_{2}\left(\mathrm{Si}_{2} \mathrm{O}_{7}\right)\right) \\
\text { Franklinite }\left(\mathrm{ZnFe}_{2} \mathrm{O}_{4}\right) \\
\text { Hematite }\left(\mathrm{Fe}_{2} \mathrm{O}_{3}\right) \\
\text { Magnetite }\left(\mathrm{Fe}_{3} \mathrm{O}_{4}\right)\end{array}$ \\
\hline \multirow[t]{2}{*}{ Mousseline } & Before & - & $\begin{array}{l}11.8 \\
1 \ldots . . .\end{array}$ & - & - & - & $\begin{aligned} 44.6 \\
. .21 .6 . .\end{aligned}$ & 43.5 & 0.1 & Cassiterite $\left(\mathrm{SnO}_{2}\right)$ \\
\hline & After & - & $\begin{array}{l}5.8 \\
. \cdots \cdots\end{array}$ & - & - & - & $\begin{array}{l}71.5 \\
\ldots \ldots\end{array}$ & 22.5 & 0.16 & Cassiterite $\left(\mathrm{SnO}_{2}\right)$ \\
\hline \multirow{2}{*}{$\begin{array}{l}\text { Depoli } \\
\text { Incolore }\end{array}$} & Before & 16.1 & 19.5 & - & - & - & 6.1 & 58.2 & 0.08 & Cassiterite $\left(\mathrm{SnO}_{2}\right)$ \\
\hline & After & 9.3 & 22.3 & - & - & - & 7.8 & 59.9 & 0.67 & Cassiterite $\left(\mathrm{SnO}_{2}\right)$ \\
\hline
\end{tabular}



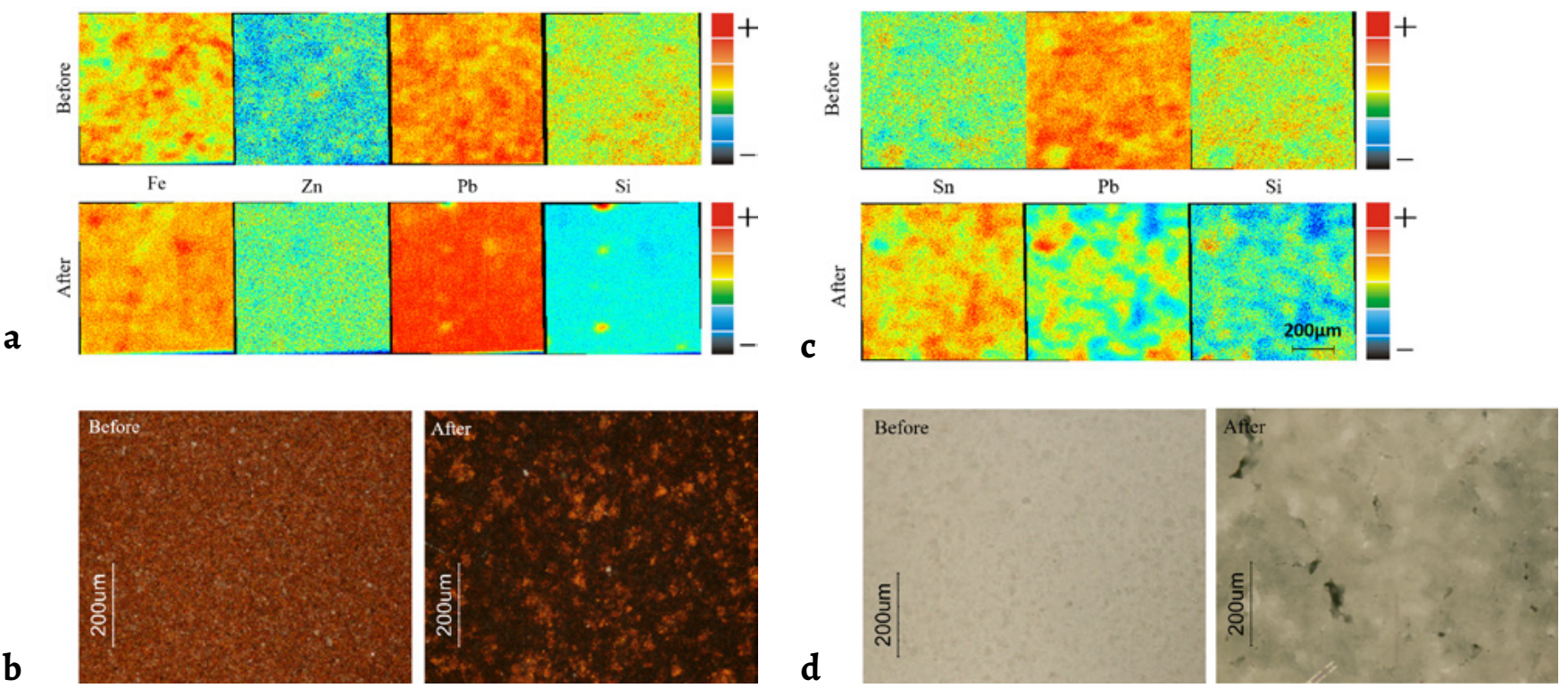

Figure 3. Mappings of elemental distribution obtained by $\mu$-PIXE $(800 \mu \mathrm{m} \times 800 \mu \mathrm{m})$ in the grisailles Brun XIII (a) and Mousseline (c); and optical microscopy images, before and after firing, with cross polar light, in the grisailles Brun XIII (b) and Mousseline (d).

conjunction with manganese or zinc in the Noir Ordinaire, Brun XIII and Brun XVI. In addition, a new phase was detected in the Noir Ordinaire after firing, the Kentrolite, which was formed due to the decomposition of the Jacobsite (Table 2). Franklinite, hematite and magnetite were still present after firing. In the case of white grisailles, it was only identified the tin oxide, cassiterite, before and after firing. Crystalline $\mathrm{SiO}_{2}$ and $\mathrm{PbO}$ were not identified in the diffractograms, because they were added in form of glassy material to favour their fusion at low temperature.

\section{Morphological characterisation}

$\mathrm{OM}$ and $\mu$-PIXE mappings of elemental distribution were performed to morphologically characterise the grisaille powder before and after the firing process. In addition, cross-sections of the painted surfaces were analysed with OM and SEM-EDS.

The results were consistent between the darker grisailles and the white ones. For this reason, it was chosen one of each group as an example of the results obtained: Brun XIII and Mousseline.

\section{Powder characterisation}

The powder characterisation, represented in the Figure 3, shows a higher degree of homogeneity in the dark grisailles after the firing process (Figure 3a); however, the optical microscopy images showed the darkening of the painted layer and the appearing of aggregates, probably related to the fusion and combination of different components (glass and metal oxides) during the firing process.

The maps of elemental distribution from Mousseline grisaille (Figure $3 b$ ), also confirmed the increase of tin after the firing process by consequence of a decrease of lead and silica. These results are in accordance to the compositional characterisation.

\section{Painted surface}

The historical grisailles used to be heterogeneous because of the presence of large metallic inclusions, bubbles, etc. [3, 5, 11-15]; but the analysed Debitus grisailles samples are very homogeneous (Figure 4). It was also possible to observe a difference between the thickness from the darker grisailles, which varies from 30 to $70 \mu \mathrm{m}$ (Figure $4 a$ ); and the white
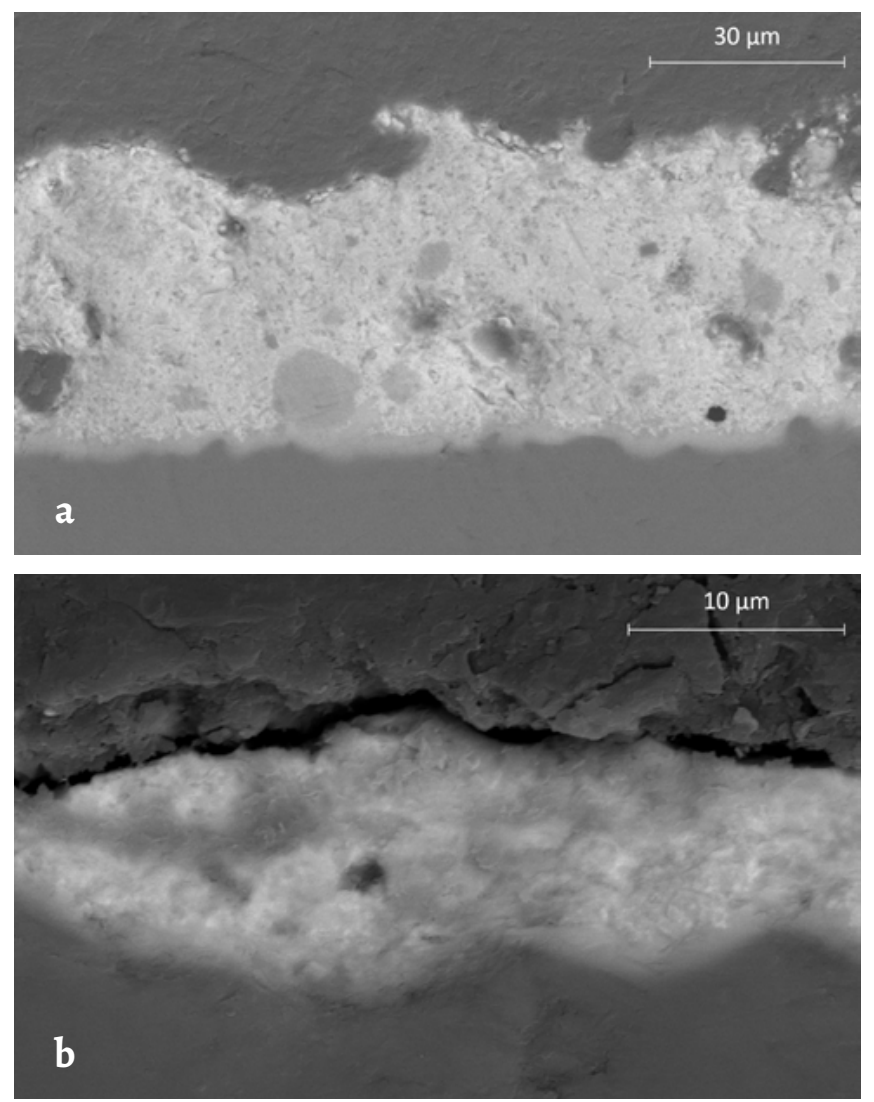

Figure 4. SEM-BSE images from the cross-section of the grisailles Brun XIII (a) and Mousseline (b). 

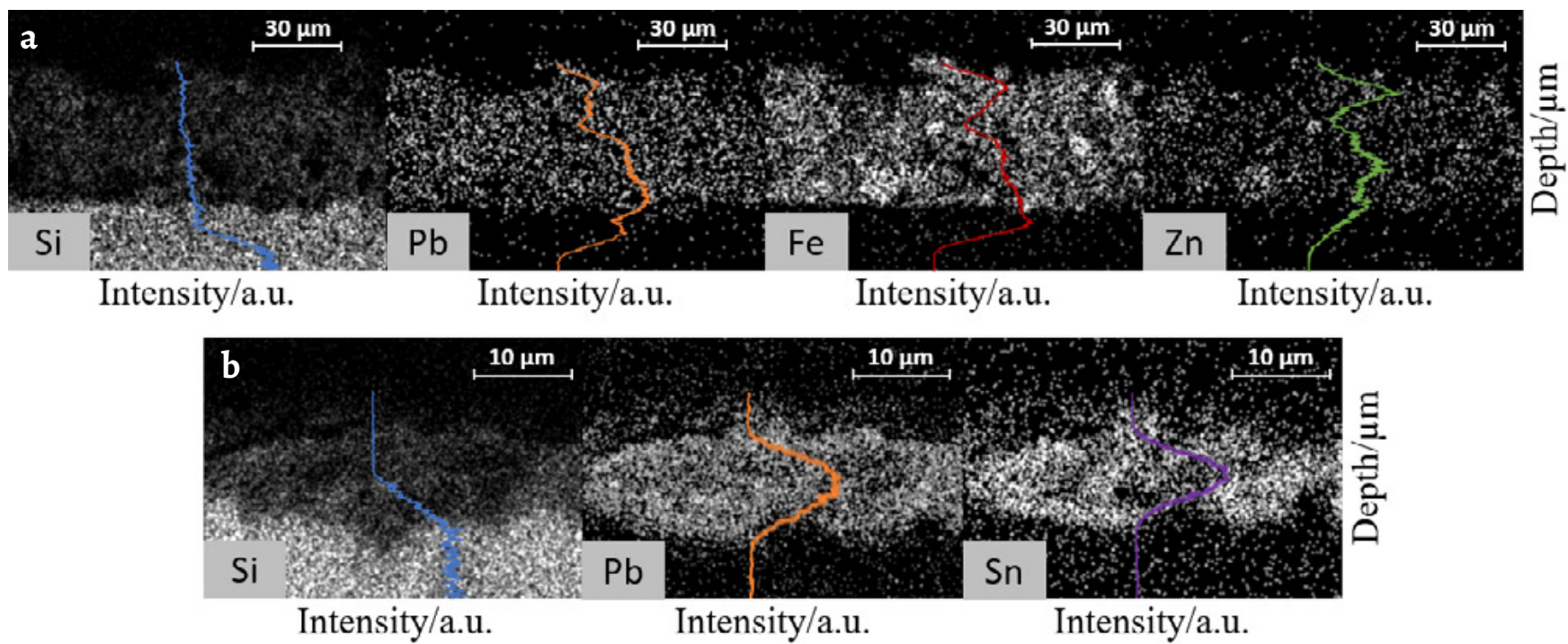

Figure 5. SEM-EDS elemental distribution of silicon, lead, iron, zinc and tin in the grisailles and representative elemental profiles of grisaille applied on glass substrates after firing Brun XIII (a) and Mousseline (b).

ones, with 10 to $25 \mu \mathrm{m}$ (Figure $4 b$ ). A smooth interface between the glass and the grisailles is also shown in Figure 4 , suggesting a good interdiffusion of the grisaille into the glass support, as well as a good adherence between the painted layer and the glass.

The cross-section profiles obtained by $\mu$-PIXE also showed the grisaille penetration into the glass matrix, which varies between the darker ones and the white ones (Figure 5). The darker grisailles presented an interface around $20 \mu \mathrm{m}$ (Figure 5a) due to the penetration of the lead on the glass support; but the interface in the white ones is around $5 \mu \mathrm{m}$ (Figure $5 b$ ). The thin interface could be due to the low content of lead in the composition after the firing process (see Chemical and crystallographic characterisation section) that could be probably related with the volatilization of this element during the thermal treatment.

The distribution of the main elements in the crosssection of the representative grisailles as determined by SEM-EDS is also presented in Figure 5. The results confirmed the homogeneity of the dispersion of the metal grains in the base-glass matrix.

\section{Thermographic characterisation}

The IR-thermographic analyses were made in reflection mode on grisailles with different thickness (thicker, medium and thinner) painted on common window glass to understand their thermal behaviour [16-19]. The samples are showed in Figure 6.

The samples showed a substantial increase of the surface apparent temperature during the exposure to the hot air flux (Figure 7, Heating) and a progressive cooling when the hot air flux was switch off (Figure 7, Cooling). It was possible to observe that the increase of the surface apparent temperature was similar in the grisailles and the glass support, being the surface temperature of grisailles slightly higher. The specific heat of the lead glasses is lower than in soda-lime silicate glasses [20-21], which means that, for the same energy, the surface paints increased more their temperature than the support glass. During the cooling, the grisailles preserved more the heat in comparison with the support glass due to the absorption of the radiation of the former ones (Figure 7).

The temperature variation between both materials was less than $2^{\circ} \mathrm{C}$ in all the cases, which indicates a good thermal compatibility. Similar results were observed in previous studies [16, 19].

When the different thicknesses are compared, the thinner layers experienced the higher increases of temperature under the same heating conditions in comparison with the thicker layers. This result is contradictory to previous studies [18]; although, these variations are not very significant since the fluctuation was less than $1^{\circ} \mathrm{C}$ and could be due to the experimental set-up.

The comparison of the different grisailles during the heating and cooling cycle is shown in the Figure 8. According to the literature, darker colours increase the surface apparent temperature more than the clear ones

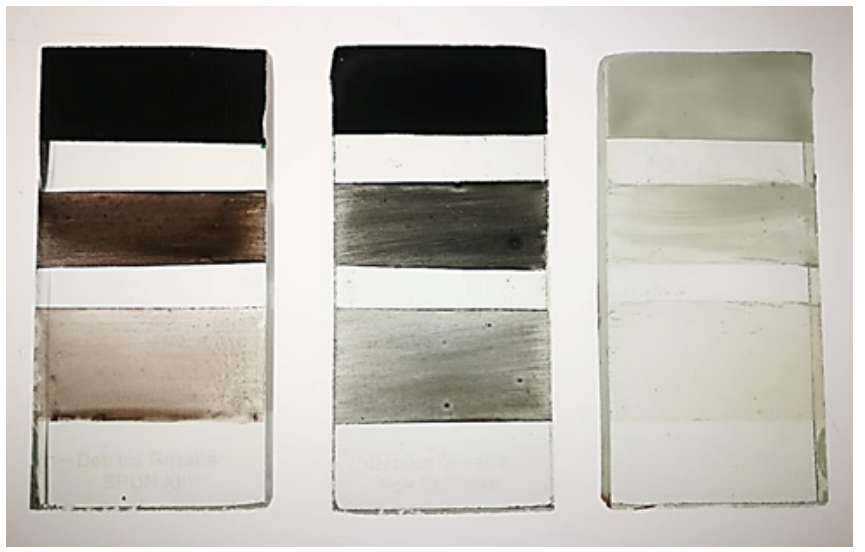

Figure 6. Painted glasses with the grisailles: Brun XIII, Noir Ordinaire and Depoli Incolore, with different thicknesses (thicker, medium, and thinner). 


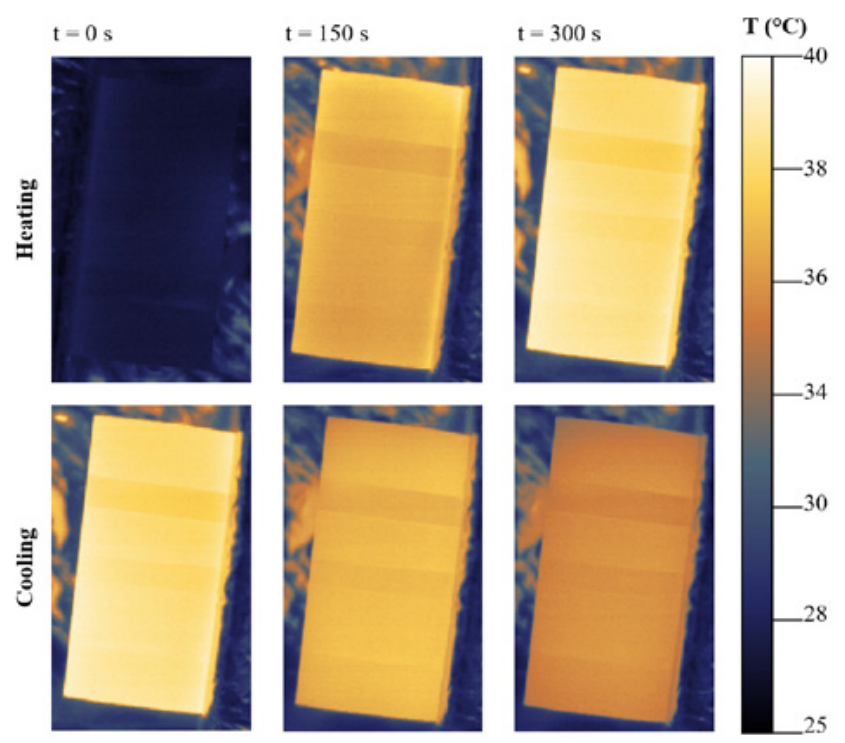

Figure 7. Surface apparent temperature map evolution in reflection mode obtained by IR-thermography from the grisaille Brun XIII.

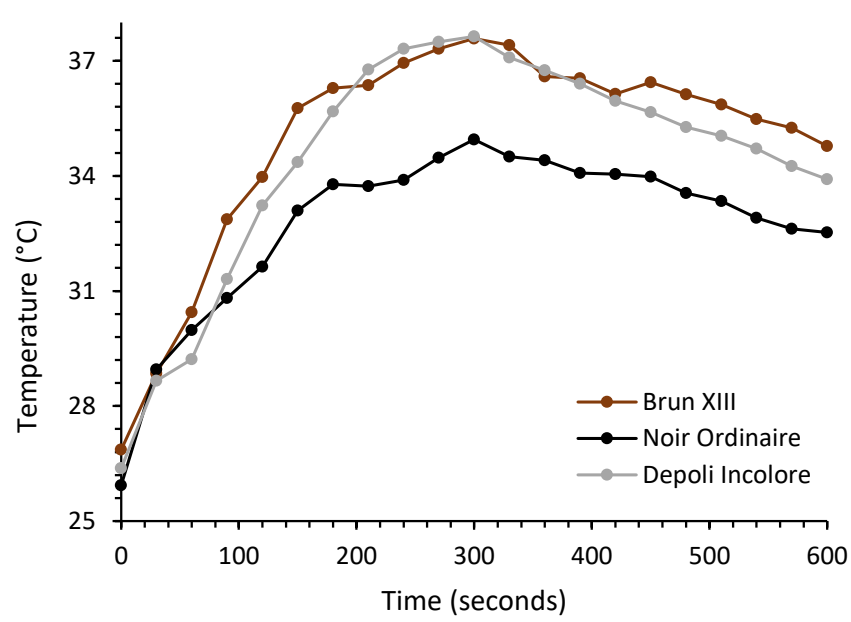

Figure 8. Comparison between the thermal variations of the different grisaille samples with the medium thickness.

under the thermal excitation of two halogen lamps due to the albedo phenomenon $[18,22]$. In this experiment, the darker grisaille, Noir Ordinaire, exhibited the lowest temperature increase, and the brown and white grisailles, with higher gloss, presented a similar behaviour between them. This difference can be related with the experimental set-up, the reflection of the IR-radiation, and/or the chemical composition of the grisailles.

\section{Conclusions}

This study allowed a current and accurate chemical, morphological and thermal characterisation of these commercial materials used in conservation and restoration works. The identification of the composition from the different grisailles enabled the understanding of a wellbalanced ratio between the different components of the raw materials. The morphological characterisation of the cross-sections showed the homogeneity of these grisailles as well as the good interdiffusion between them and the glass support. Finally, the thermal analyses of these commercial grisailles, despite the small differences in the results, indicated a good thermal stability. All these characteristics are indicative of a good quality and durable material to be used in conservation and restoration works. However, in order to fully understand the stability and durability of these commercial grisailles, further studies need to be done to assess other related factors (vehicle agents, kind of kiln or firing process), together with the behaviour and the effect of ageing on these grisaille paints.

\section{Acknowledgments}

The authors wish to thank Paulina Faria and Vitor Silva (FCT-NOVA, Portugal) for all the help and time given with the IRT. This work has been funded by the Fundação do Ministério de Ciência e Tecnologia de Portugal (project ref. UID/EAT/00729/2019 and UID/Multi/04349/2013, doctoral grant ref. PD/BD/136673/2018) and Fundación General CSIC (ComFuturo Programme).

\section{REFERENCES}

1. Machado, C.; Machado, A.; Palomar, T.; Vilarigues, M., 'Grisaille in historical written sources', Journal of Glass Studies 61 (2019), 71-86.

2. Schalm, O., Characterization of Paint Layers in Stained-glass Windows: Main Causes of the Degradation of Nineteenth Century Grisaille Paint Layers, Universiteit Antwerpen, Antwerpen (2000).

3. Pradell, T.; Molina, G.; Murcia, S.; Ibánez, R.; Liu, C.; Molera, J.; Shortland, A., 'Materials, techniques and conservation of historic stained glass "grisailles"', International Journal of Applied Glass Science 7(1) (2015) 41-58, https://doi.org/10.1111/ ijag.12125.

4. Machado, C., 'Estudo de produção de grisalhas históricas', Master dissertation, NOVA University of Lisbon - Faculty of Science and Technology, Lisbon (2016).

5. Schalm, O.; Janssens, K.; Caen, J., 'Characterization of the main causes of deterioration of grisaille paint layers in 19 th century stained-glass windows by J.-B. Capronnier', Spectrochimica Acta - Part B: Atomic Spetroscopy 58(4) (2003) 589607, https://doi.org/10.1016/S0584-8547(02)00282-3.

6. Caen, J., The Production of Stained Glass in the Country of Flanders and Duchy of Brabant from the XVth to the XVIIIth Centuries: Materials and Techniques, Brepols, Turnhout (2009).

7. 'Décoration sur verre - Historique de la grisaille', in Infovitrail, http://www.infovitrail.com/index.php/fr/histoire-de-lagrisaille (accessed in 2018-9-1).

8. Debitus, H., 'Recherche pour une formulation nouvelle de grisailles', Science et Technologie de la Conservation et de la Restauration des Oeuvres d'Art et du Patrimoine 2 (1991) 24-28.

9. RRUFF database, http://rruff.info (accessed in 2018-8-30).

10. Paints: Characteristics, http://www.debitus.com/peintures-en. php (accessed in 2018-08-30).

11. Verità, M., 'Composition, structure et mécanisme de détérioration des grisailles', in Grisaille, Jaune d'Argent, 
Sanguine, Email et Peinture à Froid, Commission Royale des Monuments, Sites et Fouilles de la Région Wallone, Liège (1996) 61-67.

12. Marschner, H., 'Analyses de pigments de grisaille sur des vitraux munichois de L'Église du Saint-Sauveur, Réalisés vers 1500', in Grisaille, Jaune d'Argent, Sanguine, Email et Peinture à Froid, Commission Royale des Monuments, Sites et Fouilles de la Région Wallone, Liège (1996) 53-59.

13. Verità, M.; Nicola, C.; Sommariva, G., 'The stained glass windows of the Sainte Chapelle in Paris: Investigations on the origin of the loss of the painted work', in Annales du 16e Congrès de l'Association Internationale pour l'Histoire du Verre, Association Internationale pour l'Histoire du Verre, Nottingham (2005) 347-351.

14. Vilarigues, M.; Silva, R. C., 'Ion beam and Infrared analysis of medieval stained glass', Applied Physics A: Materials Science and Processing 79(2) (2004) 373-378, https://doi.org/10.1007/ soo339-004-2538-9.

15. Carmona, N.; Villegas, M. A.; Fernández Navarro J. M., 'Study of glasses with grisailles from historic stained glass windows of the cathedral of León (Spain)', Applied Surface Science 252(16) (2006) 5936-5945, https://doi.org/10.1016/j.apsusc.2005.08.023.

16. Candoré, J. C.; Bodnar, J. L.; Detalle, V.; Grossel, P., 'Non destructive testing in situ, of works of art by stimulated infrared thermography', Journal of Physics: Conference Series 214 (2010) 1-9, https://doi.org/10.1088/1742-6596/214/1/012068.

17. Elmahdy, A. H. and Devine, F., 'Laboratory infrared thermography technique for window surface temperature measurements', ASHRAE Transactions 111 (2014) 561-571.

18. Palomar, T.; Machado, C.; Agua, F.; Gomez-Heras, M., 'Thermographic analysis of glasses, enamels and grisailles from stained glass windows', in Proceedings of the 5th GLASSAC International Conference, ed. I. Coutinho, T. Palomar, S. Coentro, A. Machado \& M. Vilarigues, NOVA.FCT Editorial, Lisbon (2017) 94-96.

19. Palomar, T.; Agua, F.; Gómez-Heras, M., 'Comparative assessment of stained-glass windows materials by infrared thermography', International Journal of Applied Glass Science 9(4) (2018) 530-539, https://doi.org/10.1111/ijag.12352.

20. Sharp, D. E.; Ginther, L. B., 'Effect of composition and temperature on the specific heat of glass', Journal of the American Ceramic Society 34(9) (1951) 260-271, https://doi.org/10.1111/j.1151-2916.1951.tbo9128.x.

21. Navarro, J., El Vidrio, 3rd edition, Editorial CSIC, Madrid (2003).

22. Zúñiga López, I.; Crespo del Arco, E., Meteorología y Climatología, 2nd edition, Editorial UNED, Madrid (2010).
RECEIVED: 2018.12 .9

REVISED: 2019.4 .5

ACCEPTED: 2019.4.29

ONLINE: 2019.5.17

\section{(1) (1) (3)}

This work is licensed under the Creative Commons Attribution-NonCommercial-NoDerivatives 4.0 International License. To view a copy of this license, visit http://creativecommons.org/licenses/by-nc-nd/4.o/deed.en. 